A BIOGRAPHY OF NO PLACE 



\section{A Biography of No Place}

\section{From Ethnic Borderland to \\ Soviet Heartland}

Kate Brown

HARVARD UNIVERSITY PRESS

Cambridge, Massachusetts

London, England 2003 
Copyright ( 2003 by Kathryn L. Brown

All rights reserved

Printed in the United States of America

\section{Library of Congress Cataloging-in-Publication Data}

Brown, Kate.

A biography of no place : from ethnic borderland to Soviet heartland / Kate Brown.

p. $\mathrm{cm}$.

Includes bibliographical references index.

ISBN 0-674-01168-6 (alk. paper)

1. Former Polish Eastern Territories--History. 2. Former Polish Eastern

Territories--Ethnic relations. 3. Pluralism (Social sciences)--Former Polish Eastern Territories. I. Title.

DK500.F67B76 2003
947.7' $8084--$ dc22 2003056683


For Dave and Sasha, my favorite traveling companions 
